Cahiers $d u$ MONDE RUSSE

\section{Cahiers du monde russe}

Russie - Empire russe - Union soviétique et États indépendants

$50 / 2-3 \mid 2009$

L'Europe orientale, 1650-1730. Crises, conflits et renouveau

\title{
Kazakhstan: Ethnicity, Language and PowerBhavna DAVE
}

, London - New York : Routledge, 2007, 242 p.

Niccolò Pianciola

\section{(2) OpenEdition}

\section{Journals}

\section{Édition électronique}

URL : https://journals.openedition.org/monderusse/9784

DOI : 10.4000/monderusse. 9784

ISSN : $1777-5388$

\section{Éditeur}

Éditions de l'EHESS

\section{Édition imprimée}

Date de publication : 15 septembre 2009

ISBN : 978-2-7132-2260-3

ISSN : $1252-6576$

Référence électronique

Niccolò Pianciola, «Kazakhstan: Ethnicity, Language and PowerBhavna DAVE », Cahiers du monde russe [En ligne], 50/2-3 | 2009, mis en ligne le 14 janvier 2013, consulté le 03 septembre 2022. URL http://journals.openedition.org/monderusse/9784; DOI : https://doi.org/10.4000/monderusse.9784

Ce document a été généré automatiquement le 3 septembre 2022

Tous droits réservés 


\section{Kazakhstan: Ethnicity, Language and PowerBhavna DAVE}

, London - New York : Routledge, 2007, 242 p.

Niccolò Pianciola

\section{Bhavna DAVE, Kazakhstan: Ethnicity, Language and Power, London - New York: Routledge, 2007, 242 p.}

1 Bhavna Dave relies upon three different streams of scholarly enquiry ("the new Western historiography of the Soviet era, the postcolonial theory and the ethnographies of postsocialist transition," p.11) in order to analyze the evolution of Kazakh "national consciousness", as embedded in pre-Soviet, Soviet and post-Soviet power relations. The question is explored principally in terms of the language policies adopted in the Soviet and post-Soviet periods. In Dave's words, "the crucial argument of the book is that the depiction of Soviet rule in Kazakhstan and Central Asia is predominantly colonial or imperial, and the portrayal of Central Asians as powerless subjects and recipients of Soviet modernity are both simplistic and inaccurate. [...the book] details how the Soviet socialist state, through a mix of coercive, paternalistic and egalitarian measures, forged a distinct sense of ethnic entitlement among its nations or 'subjects.' A growing assertion of ethnic entitlements went hand in hand with a steady depoliticization of ethnicity." (p. 5)

2 The first part of the book relates the integration of Kazakhs in the Soviet system and their participation in the elaboration of Soviet "categories and parameters" (p. 6), a process which led to the formation of a "hybrid" Kazakh-Soviet "identity" (p. 5). The second part explores the legacy of these categories in the post-Soviet period, in order to explain why Kazakh intellectuals, the political elite and lower social strata did not make the postcolonial quantum leap, freeing their "national" discourse from the Soviet categorial cage.

3 The first chapter is an accurate exposition of different historiographic interpretations of Soviet rule in Central Asia. Dave provides some insightful comparisons, such as an 
analysis of the differences between state-building and the imperial mission civilisatrice, relying on Eugen Weber's work on nineteenth-century France (p. 16-17). It is unfortunate that in the chapter that follows, which lays the historical foundations of Dave's analysis, factual errors abound. To cite only a few: in 1917 there was, purportedly, "a general consensus among the various groups of Kazakh intelligentsia, Russian-educated administrative functionaries, clan leaders and ordinary nomads [!] that nomadic pastoralism was becoming unsustainable and had to adapt itself to new challenges" ( $p$. 46); the author seems to think that the main political divide during the civil war was between Bolsheviks and Mensheviks (p. 42); she predates the forced collectivization of agriculture to the period 1925-1929 (the assertion is repeated many times); hojas are referred to as "the clergy" (p. 32); the Turkestani and Kazakh Communist Turar Ryskulov in 1922 supposedly "admitted that the Alash-Orda was the most legitimate representative of Kazakh interests, and not a tribal-nationalist group as the Bolsheviks had maintained" (p. 47) - at a time when Ryskulov was a high-ranking Bolshevik official in Turkestan's government.

Chapters 3 and 5, dedicated to language policies respectively in Soviet and post-Soviet times, are the book's best. In postfamine Soviet Kazakhstan, social promotion (which for Kazakhs usually entailed urbanization) was directly linked to the mastery of the Russian language, which often went hand in hand with a loss of proficiency in Kazakh. According to one of Dave's informants, Kazakh students at Alma-Ata University in the 1940s "did not want to use Kazakh, not even among themselves, even though many of them did not speak good Russian" (p. 65). Alma-Ata and the majority of the cities in Kazakhstan remained largely Russian (in terms both of urban landscape and population) until the fall of the Soviet Union. In the 1950s not a single Kazakh-language school was present in the capital. A new societal divide between urbanite Russian-speaking Kazakhs and rural Kazakh-speakers was thus created. During the Soviet era, most Kazakh intellectuals were Russian-speakers. In dealing with the language policies of post-Soviet Kazakhstan, Dave makes a comparison with similar policies in postcolonial Asia (Sri Lanka, India and Malaysia), and convincingly argues that Kazakhstan "has avoided potential social conflict or politicization of the language issue by refraining from adopting a cultural or linguistic transformation agenda" (p. 117). In other words, because of the strong linguistic Russification of the Kazakh social and political elite, the state did not try to eradicate the predominance of Russian, even though it promoted an increased use of Kazakh in the administration and the media. Although Kazakh nationalist groups advocating stronger support for the use of the Kazakh language have been present over the last twenty years, "'pure' Kazakh speakers are an economically and socially weak group that cannot mobilize cultural or linguistic claims without state support." (p. 112) Therefore post-Soviet Kazakhstan provides one of the clearest examples of "symbolic language politics," where language becomes a symbol of state independence and national assertion, while its use "in the public domain or in interpersonal settings is largely unaffected." (p. 97) However, here Dave underestimates the effects of post-Soviet social transformations, such as the urbanization of large numbers of Kazakh-speakers, and their access to institutions of higher education.

5 Another chapter describes the construction of clientelist networks in postwar Kazakhstan, showing the effectiveness of Soviet priority policies for jobs and higher education based on nationality in empowering a clientelist network managed by the top echelons of the party of each national republic. In Kazakhstan the personification of this system was Dinmukhammed Kunaev, at the head of Kazakhstan Communist Party almost 
continuously from 1960 to 1986 . The description of this "Brezhnevian political contract" is, however, quite superficial, given the difficulty of finding documentation, oral or written. The assumed crucial role of the clans derives from Ed Schatz's and Kathleen Collins' works and it is not substantiated by original research. ${ }^{57}$

Dave then proceeds to explain why the dog of nationalism did not bark in demographically Russian-dominated Northern Kazakhstan. She reminds readers that "almost all ethnic mobilizations during the glasnost era and the post-Soviet period have occurred via existing Soviet-created institutional channels" (p. 121). Since Russians in Kazakhstan lacked an ethnic territorial unit of their own, they also lacked administrative tools and a local political elite capable of presenting their grievances. The vast majority of them chose the "exit" option, and emigrated en masse during the 1990s from the newly independent republic, ravaged by the dissolution of the Soviet economic system. Dave reminds us that in Kazakhstan, as in other post-Soviet states, the legacy of the Soviet system largely prevented the formation of ethnic economic niches. Amy Chua notwithstanding, no ethnic groups formed an entrepreneurial diaspora in post-Soviet states comparable to, say, the Chinese in Malaysia in the 1960s.

Dave's analysis of the symbolic and pragmatic character of nationalizing policies in post-Soviet Kazakhstan is careful but breaks little new ground. She makes some interesting specific points, and accurately describes the power balance in the republic between different economic-political groups (even though the picture has now changed, after the exile of Nazarbaev's son-in-law Rakhat Aliev). The overall problem of the book is its unresolved methodological ambiguity between anthropology, history and political science. The author claims that one of her main research efforts was the reconstruction of family histories; and that she put together seven of them (p. 174-175). Unfortunately, the reader does not see this potentially very interesting information in the text. Dave also worked in one archive in Kazakhstan (the former party archive in Almaty), but she provides references to only four files (dela) in the whole book (this documentation offers some small pieces of attention-grabbing information about the situation in the education system during the 1950s). In her attempt to bring together the historiography of the Soviet era, postcolonial theory, subaltern studies and ethnographies of postsocialism, Dave falls victim to the fact that Kazakhstan has been marginal for all these disciplinary approaches. The author's tendency to take for granted bold assumptions made by single authors (such as the late Nurbulat Masanov's views on Kazakh nomadism), does not help the search for new interpretations. Most importantly, after having convincingly pointed out the radical differences between post-Soviet Kazakhstan and postcolonial South and South-East Asia, Dave somehow contradictorily remains stuck in postcolonial studies phraseology. She supports a de-Russification of Kazakh "identity", since "a successful postcolonial nationalist project rests on [in Partha Chatterjee's words] 'superseding the conditions of colonial rule"' (p. 171). Dave believes that only a truly democratic society with an open public sphere where different conceptions of "national identity" and "national revival" exist will be able to prompt this "decolonization of the national imagination" (p. 171). She fails to explain, however, why, in a society where Kazakhs are only half of the population, a democratic public sphere should be focused on the creation of a "nationalist project" (p. 171). One is left to wonder whether in most situations becoming resigned to one's own "hybrid identity" (in itself a problematic category of analysis) would not be a better option. 


\section{NOTES}

57. Edward Schatz, Modern Clan Politics: The Power of "Blood" in Kazakhstan and Beyond, Seattle-London: University of Washington Press, 2004; Kathleen Collins, Clan Politics and Regime Transition in Central Asia, Cambridge, MA: Cambridge University Press, 2006. 